\title{
Application of vertical gardening technology in high-rise construction
}

\author{
Alexander Ischenko*, Daria Shishkunova \\ Moscow State University of Civil Engineering, 129337, Moscow, Russia
}

\begin{abstract}
In the modern world, urban areas are gradually replacing natural areas, which, in turn, negatively affects the environmental situation of the city. To solve this problem, people began to think about greening megalopolises in such a way that it did not occupy useful areas of the urban environment. The solution to this problem is possible by using vertical gardening technology in high-rise construction, which turns gray walls into vertical gardens. This technology allows not only decorating city streets, but also to significantly increase energy efficiency, create a natural environment, and have a positive impact on the psycho-emotional state of a person. This paper discusses various vertical gardening technologies for high-rise construction.
\end{abstract}

\section{Introduction}

In the context of modern construction and an increase in the rate of development of residential space with high-rise buildings, the deterioration of the ecological situation in the city increases. This is caused by the growth of population, the compaction of urban development, a decrease in the area of urban greening, an increase in artificial, stone cover, and the lack of territories for creating recreational zones, which is a big problem for the modern world. Therefore, it is necessary to look for new ways to return natural complexes to the structure of the city.

In large cities, factories and almost all types of transport are the main sources of pollution. The produced gas pollution, dust and noise, cause colossal damage to the ecological situation of the urban environment. However, the solution to this environmental problem is possible without the implementation of fundamental methods of changing the urban infrastructure, without demolishing the existing buildings and without reducing the asphalt pavement in the city.

Environmental quality assessment is determined using rating systems.

The most famous systems are LEED (USA); BREAM (UK); DGNB (Germany); Green Star (Australia); CASBEE (Japan); Minergie (Switzerland).

Russia has developed a rating system - Green Standards.

\footnotetext{
* Corresponding author: Ishchenko.AB@yandex.ru
} 
The introduction of environmentally friendly materials, energy-efficient and energysaving technologies is the basis for improving the ecological situation in the urban environment.

\section{Materials and methods}

One of the important innovative technologies is the use of vertical gardening (VG) in highrise construction. This approach has a positive effect on the following indicators:

- the level of the maximum permissible concentration of harmful substances in the air;

- energy consumption;

- reduction of heat loss through enclosing structures;

- increasing thermal insulation;

- protection against noise and dust;

- shading the space from sunlight and thereby cooling the area due to moisture evaporation.

\section{Energy Efficiency \\ Using less energy by providing the same \\ level of productivity and comfort}

\section{Water Efficiency \\ Managing water usage by \\ reducing waste}

Environmental Protection

Transportation accessibility, green areas

\section{Indoor Environmental Quality}

High-level comfort through temperature, humidity and lighting control

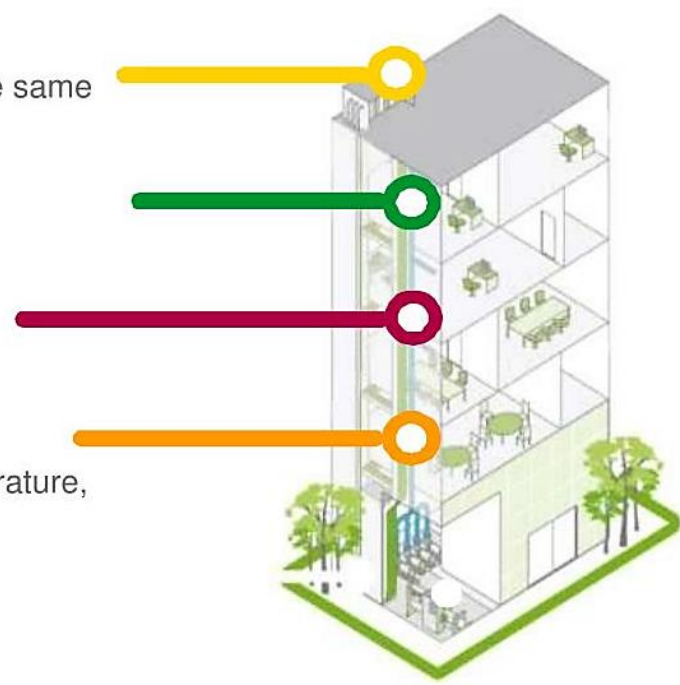

Fig. 1. The use of vertical gardening technology.

Today, the most important task in the construction of a high-rise building is energy efficiency.

The energy efficiency of high-rise buildings is a single system that includes the mutual influence of the building with the environment, interaction, and interdependence on each other.

The use of a vertical gardening system provides a solution to some functional tasks in high-rise construction:

- Greening does not allow some ultraviolet radiation to pass through, protecting the room from direct sunlight, shading the area.

- The indoor climate improves, making the air fresher, cleaner and cooler, which reduces the need for air conditioning, helping to reduce energy costs.

- Greening lowers the temperature of the outer walls of the building, reducing the flow of heat into the rooms. If deciduous vegetation is used for greening, then the premises will be shaded in summer, and in winter, sunlight will freely penetrate into the house.

- Vertical gardening of the walls enriches the surrounding air space with oxygen, creating more comfortable living conditions. Foliage absorbs sound: studies show that green 
plants on the façade reduce background noise by up to $50 \mathrm{~dB}$. So, the noise of the street and the sounds of traffic will not interfere with the privacy of the residents of the house.

- The exterior of a building can change its colors depending on the season. This is achieved by using various plants and flowers for landscaping, which, when blooming, will transform the facade of the building beyond recognition. Flowering plants will attract bees and other insects, creating a unique atmosphere of unity with nature.

Conceptually, two types of vertical gardening of high-rise buildings can be distinguished:

1. "Vertical forest". A technology based on the construction of special platforms, consoles or terraces on the facade of the building. In such specialized places, mobile containers with soil are installed and plants (lawn, shrubs, trees) are planted (Figure 2).
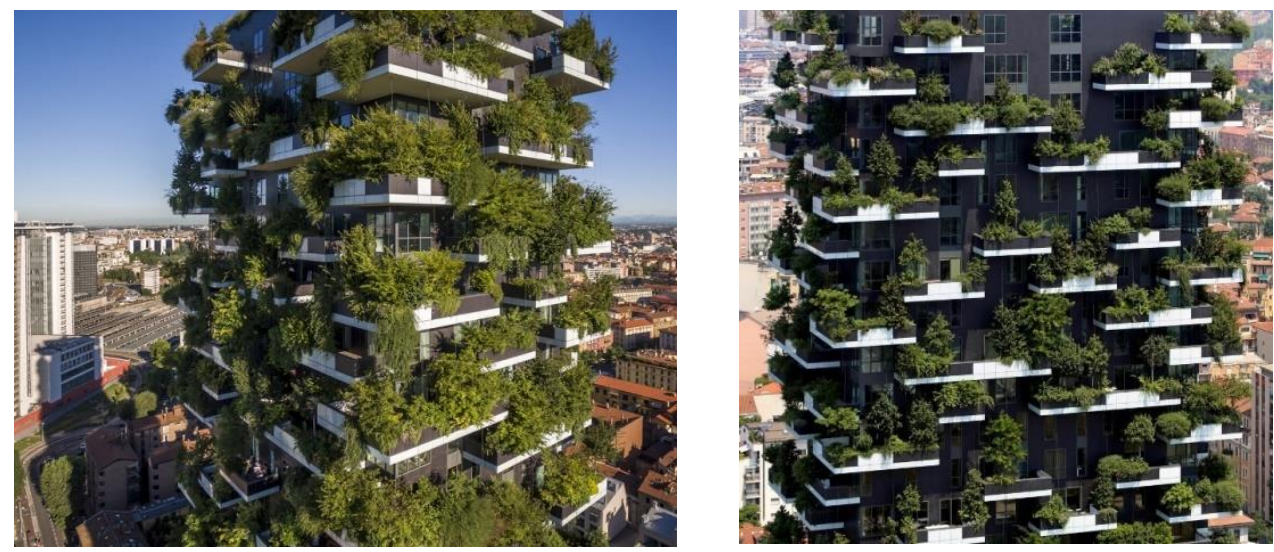

Fig. 2. Vertical greening system "Vertical Forest".

2. "Living Wall". This type of VG provides for the installation of a special modular rack for placing vegetation directly on it (Figure 2, Figure 3).
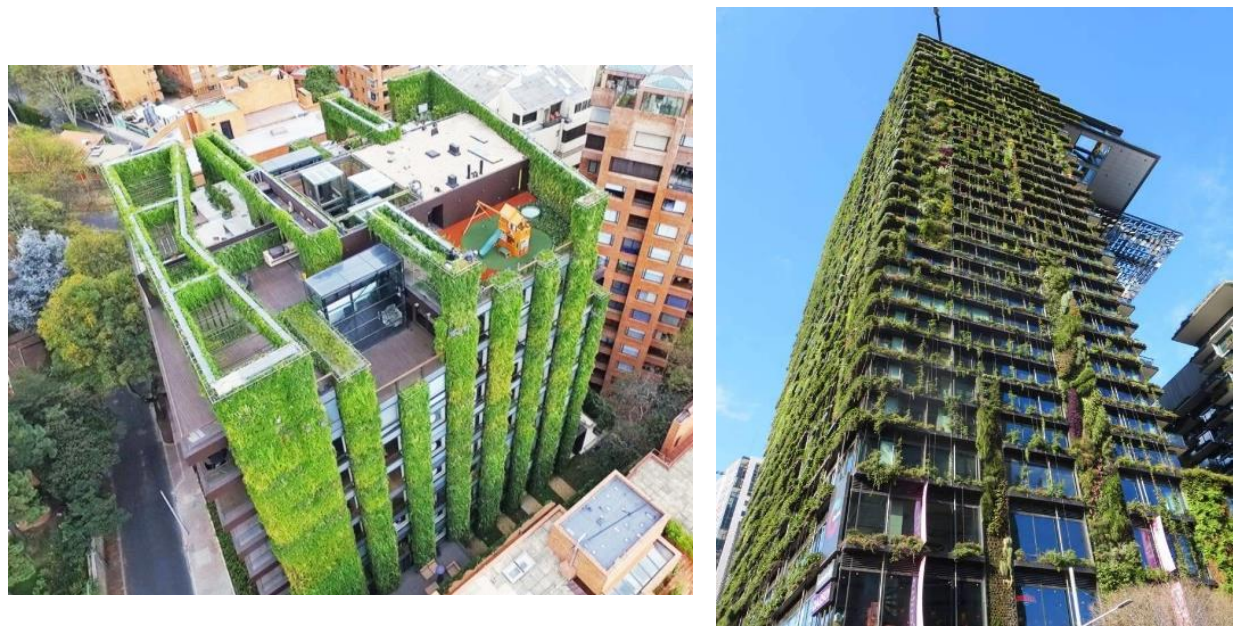

Fig. 3. System of vertical gardening “Living Wall”.

In turn, living walls are divided into several types:

I. Panel systems (using a substrate)

II. Felt systems (hydroponic) 
III. Container systems (planting in pots)

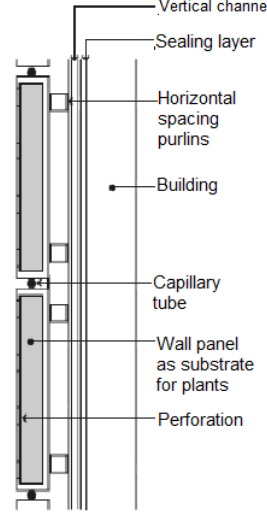

PANEL SYSTEM

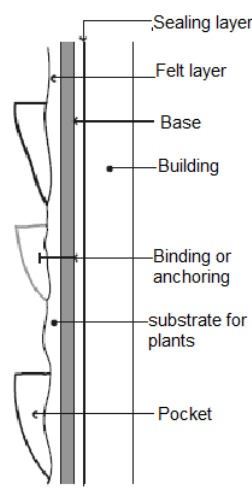

FELT SYSTEM

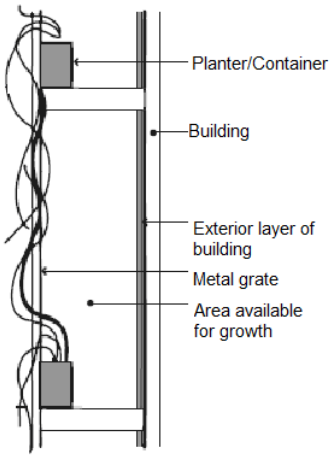

CONTAINER AND/OR GRATE SYSTEM

Fig. 4. Vertical gardening technology "Living Wall”.

Panelsystems (using a substrate) are a structure of several separate elements (panels) (Figure 5). They can be made of various materials (metal, plastic, etc.). After mounting a special metal frame, racks with brackets are attached to it. They have a clearly regulated step for fixing the panels. The final stage is the installation of an irrigation system. Plants are planted in each panel separately, after which the system is assembled into a single whole.
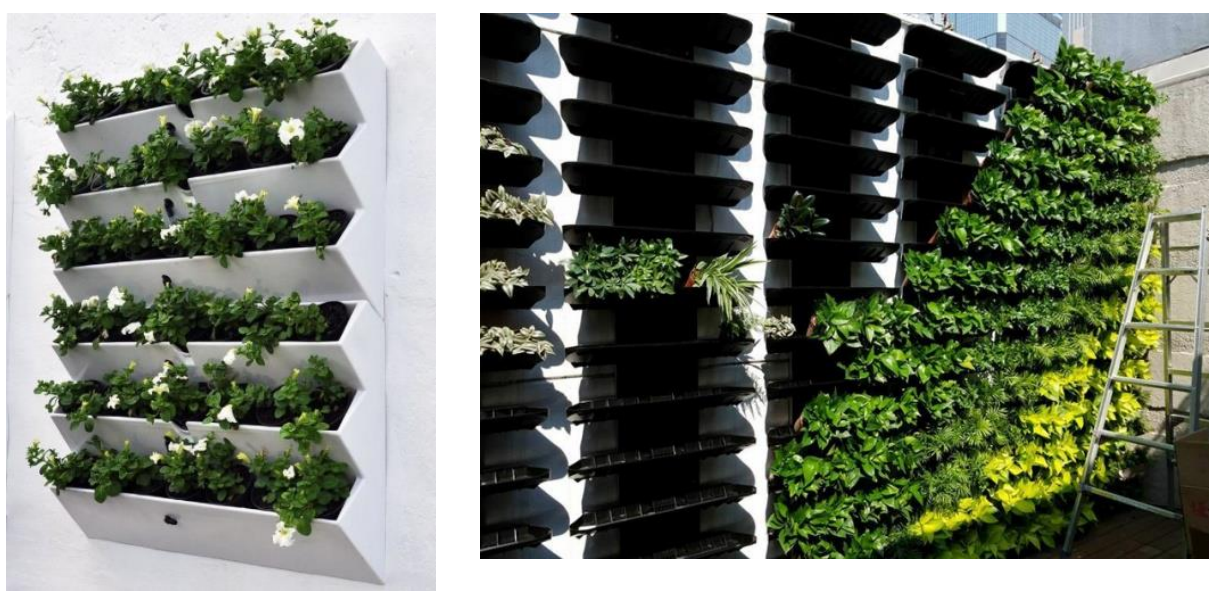

Fig. 5. Panel vertical gardening system.

Felt (hydroponic) greening system is gaining popularity among vertical gardening systems (Figure 5). For its creation, a durable felt material is used, equipped with pockets for planting greenery. Pockets are made of thick fabric of the required size, after which they are attached to the frame. The frame is the basis of the rack, which is fixed directly to the wall of the building. In this structure, a drainage and drip irrigation system is made. The necessary plants are planted in special pockets, thereby decorating the wall space. 

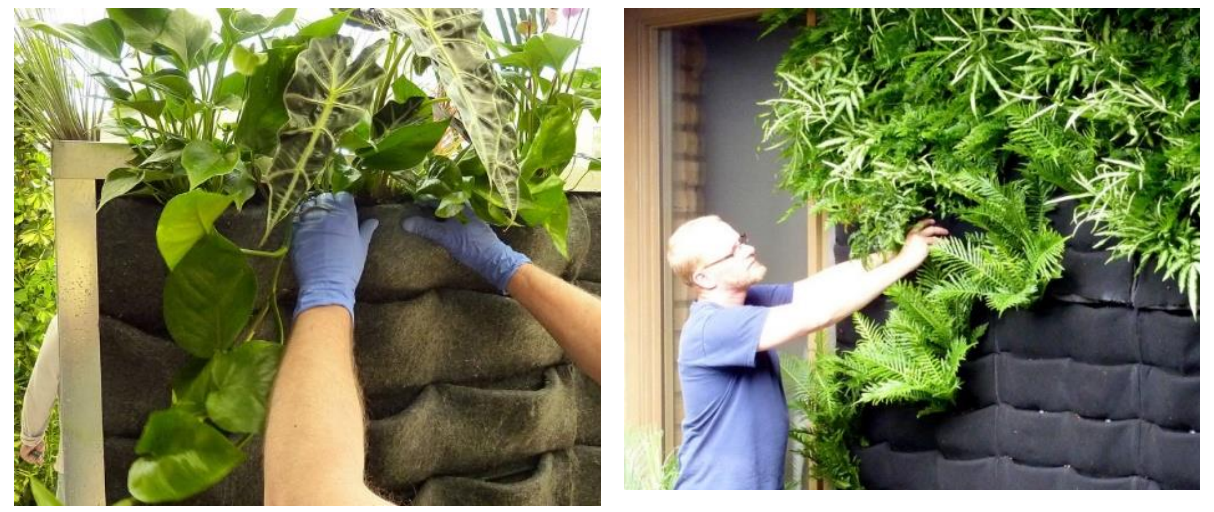

Fig. 6. Felt vertical gardening system.

The container system (potting) is a one-piece decorative structure (Figure 7). It is carried out using a wireframe, mesh for cells. An irrigation system is installed in the frame, soil slopes for planting plants are fixed. Each pot has an individual fertilizer and water supply tube.

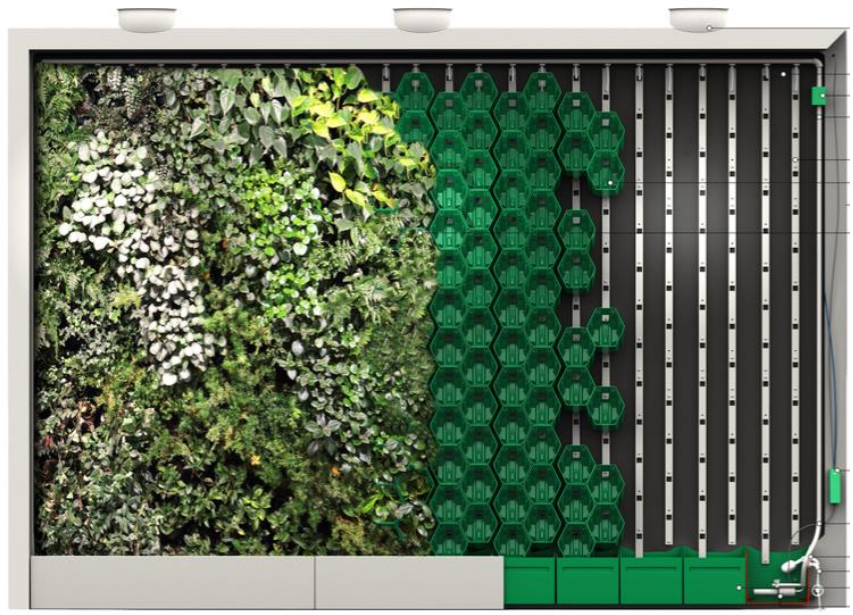

Fig. 7.Container system for vertical gardening.

\section{Results}

In order to determine the optimal technology for vertical gardening of the building facade, a comparative analysis of each system was performed (Table 1).

Table 1. Comparative analysis of each system.

\begin{tabular}{|c|c|c|c|}
\hline $\begin{array}{c}\text { Comparison } \\
\text { criterion }\end{array}$ & Felt system & Panel system & Container system \\
\hline $\begin{array}{c}\text { Installation } \\
\text { method }\end{array}$ & Felt pockets & Inventory panels & Containers (pots) \\
\hline
\end{tabular}




\begin{tabular}{|c|c|c|c|}
\hline Irrigation system & $\begin{array}{l}\text { Based on } \\
\text { hydroponic } \\
\text { nutrition }\end{array}$ & $\begin{array}{l}\text { Based on } \\
\text { hydroponic } \\
\text { nutrition. }\end{array}$ & $\begin{array}{l}\text { Carried out through } \\
\text { the pipe system }\end{array}$ \\
\hline Drainage system & Yes & No & No \\
\hline Operation / care & Periodic & Periodic & Constant \\
\hline $\begin{array}{l}\text { Changing } \\
\text { configurations }\end{array}$ & $\begin{array}{l}\text { Cannot be } \\
\text { changed, } \\
\text { complete } \\
\text { dismantling } \\
\text { required }\end{array}$ & $\begin{array}{l}\text { Partially possible. } \\
\text { Rearrange is } \\
\text { carried out by } \\
\text { panels. }\end{array}$ & $\begin{array}{l}\text { Change is possible } \\
\text { by moving } \\
\text { independent } \\
\text { containers. }\end{array}$ \\
\hline $\begin{array}{l}\text { Environmental } \\
\text { pollution }\end{array}$ & Minimum & Minimum & Moderate \\
\hline Greening type & $\begin{array}{c}\text { Complete } \\
\text { greening, } \\
\text { selective greening } \\
\text { (rare) }\end{array}$ & $\begin{array}{c}\text { Complete } \\
\text { greening(rare), } \\
\text { selective greening }\end{array}$ & $\begin{array}{l}\text { Complete greening, } \\
\text { selective greening }\end{array}$ \\
\hline
\end{tabular}

Based on the analysis from Table 1, it can be concluded that the most acceptable greening system is based on felt pockets, which is suitable for solid, blank walls. However, if partial greening is required, then it is better to choose a panel system. It is the most mobile and unpretentious to various design changes.

To determine the economic justification for vertical gardening, an aggregated calculation of each system was carried out (at prices as of 01.12.2019). Selected greening area $-500 \mathrm{~m}^{2}$.

(Table 2 - Table 4).

Table 2. The aggregated cost of installing a felt vertical gardening system.

\begin{tabular}{|c|c|c|c|c|}
\hline Name & Quantity & $\begin{array}{c}\text { Un. } \\
\text { mes. }\end{array}$ & $\begin{array}{c}\text { Price per } \\
\text { piece, rub. * }\end{array}$ & $\begin{array}{c}\text { Prices for } \\
\text { everything, rub. }\end{array}$ \\
\hline Water tank for irrigation & 21 & pcs. & 3200 & 67200 \\
\hline Pipe D16" & 2940 & $\mathrm{~m}$ & 100 & 294000 \\
\hline Felt pockets 20x20 cm & 12600 & pcs. & 1.89 & 23814 \\
\hline PVC & 84 & pcs. & 9905 & 832020 \\
\hline Hydrogel & 189 & kg & 1300 & 245700 \\
\hline Rack profile 300x10x5 cm & 399 & pcs. & 180 & 71820 \\
\hline Fastenings for a profile & 735 & pcs. & 38 & 27930 \\
\hline Water regulation timer & 21 & pcs. & 4024 & 84504 \\
\hline Total: & & & & 1646988 \\
\hline
\end{tabular}


Table 3. The aggregated cost of installing a panel vertical gardening system.

\begin{tabular}{|c|c|c|c|c|}
\hline Name & Quantity & $\begin{array}{c}\text { Un. } \\
\text { mes. }\end{array}$ & $\begin{array}{c}\text { Price per } \\
\text { piece, } \text { rub. } *\end{array}$ & $\begin{array}{c}\text { Prices for everything, } \\
\text { rub. }\end{array}$ \\
\hline PipeD16" & 1575 & $\mathrm{~m}$ & 100 & 157500 \\
\hline $\begin{array}{c}\text { Phytomodules40x42x3.2 } \\
\text { cm }\end{array}$ & 2940 & pcs. & 5000 & 14700000 \\
\hline PVC & 84 & pcs. & 9905 & 832020 \\
\hline Hydrogel & 84 & pcs. & 1300 & 109200 \\
\hline $\begin{array}{c}\text { Rack profile 300x10x5 } \\
\text { cm }\end{array}$ & 399 & pcs. & 180 & 27930 \\
\hline Fastenings for a profile & 735 & pcs. & 38 & 141120 \\
\hline $\begin{array}{c}\text { Fastenings for attaching } \\
\text { a panel to the bracket }\end{array}$ & 5880 & pcs. & 24 & 84504 \\
\hline Water regulation timer & 21 & pcs. & 4024 & 16124094 \\
\hline Total: & & & & 240 \\
\hline
\end{tabular}

Table 4. The aggregated cost of installing a container vertical gardening system.

\begin{tabular}{|c|c|c|c|c|}
\hline Name & Quantity & $\begin{array}{c}\text { Un. } \\
\text { mes. }\end{array}$ & $\begin{array}{c}\text { Price per } \\
\text { piece, rub. } *\end{array}$ & $\begin{array}{c}\text { Prices for everything, } \\
\text { rub. }\end{array}$ \\
\hline Pipe holder D16" & 5670 & pcs. & 18 & 102060 \\
\hline $\begin{array}{c}\text { Serrated T-shaped } \\
\text { fitting D16" }\end{array}$ & 12600 & pcs. & 71 & 894600 \\
\hline $\begin{array}{c}\text { Serrated L-shaped } \\
\text { fitting D16” }\end{array}$ & 1239 & pcs. & 68 & 84252 \\
\hline PlugD16" & 21 & pcs. & 11 & 231 \\
\hline \begin{tabular}{c} 
Drip tip 5x3MM. \\
\hline Pipe D16”
\end{tabular} & 2940 & m & 100 & 294000 \\
\hline $\begin{array}{c}\text { Container (pot) } \\
\text { 20x20x20 cm }\end{array}$ & 12600 & pcs. & 32 & 403200 \\
\hline Wireframe mesh & 42 & pcs. & 754 & 31668 \\
\hline Soil & 44100 & 1 & 8 & 361620 \\
\hline $\begin{array}{c}\text { Rack profile } \\
\text { 300x10x5 cm }\end{array}$ & 399 & pcs. & 180 & 71820 \\
\hline $\begin{array}{c}\text { Fastenings for a } \\
\text { profile }\end{array}$ & 735 & pcs. & 38 & 27930 \\
\hline
\end{tabular}




\begin{tabular}{|c|c|c|c|c|}
\hline $\begin{array}{c}\text { Water regulation } \\
\text { timer }\end{array}$ & 21 & pcs. & 4024 & 84504 \\
\hline Total: & & & & 2544885 \\
\hline
\end{tabular}

The analysis showed that, from an economic point of view, the cheapest greening system is the felt one. While the panel system is the most expensive. Undoubtedly, the use of the vertical gardening felt system is more profitable on large areas. It is convenient for maintenance, because it has an automatic system for supplying fertilizers and irrigation. However, this system does not have the ability to quickly re-plan and change the structure, which makes it impossible to quickly change the design of the entire system. It can only be completely dismantled, changed and re-installed.

The panel system, along with the felt one, is based on an automatic irrigation and fertilization system (hydroponics). The system is mobile and easily undergoes various transformations. The panels are independent and can be easily removed, replaced and rebuilt, while changing the overall appearance of the building facade. However, the high cost casts doubt on the use of this system in vertical landscaping of high-rise buildings.

The container system is the most available in greening organization. The installation of such a lgreening system requires a minimum amount of time and preparation. This system is mobile, transformable, and consists of standard components. The disadvantage is maintenance, which requires constant fertilization, watering and pest control.

\section{Conclusions}

The use of vertical gardening technology in the design and construction of a high-rise building, already at the operational stage, allows:

1) reducing the energy loss of the building;

2) reducing resource consumption;

3) improving noise reduction;

4) increasing dust collection;

5) lowering the level of maximum permissible concentration of harmful substances in the air.

The use of modern technologies, the skillful implementation of new methods and the modernization of existing ones to improve the environmental friendliness of high-rise buildings make it possible to reduce the negative impact of high-rise urban development on the ecological situation in the city, improving the environmental situation as a whole.

\section{References}

1. A.A. Lapidus, V.I. Telichenko, D.K. Tumanov, M.N. Ershov, P.P. Oleinik, O.A. Feldman, A.V. Ishin, Technology and organization of construction production, 2, 10 (2014).

2. P.P. Oleinik, V.I. Brodsky, Organizational forms of construction, Scientific publication Textbook (2015).

3. S.A. Sinenko, E.D. Danilova, BST: Bulletin of construction equipment, 5 (1005) 54 (2018).

4. R. Duballet, O. Baverel, J. Dirrenberger, Automation in Construction, 83247 (2017).

5. B.A. Lyovin, R.R. Kazaryan, V.O. Chulkov, In fographics of anthropotechnical management. Infographic modeling in the mental activity philosophy (Moscow) 2016 
6. B.A. Lyovin, R.R. Kazaryan, V.O. Chulkov, Infographics of anthropotechnical management. Conception of advanced development of anthropotechnical security of functioning and life quality (Moscow) 2016.

7. S. Mehmet, C.K. Yusuf, Energy Procedia 134702 (2017).

8. F. Ramírez, M.J.M. Davis, S. Chuquer and A. Vallejo, Calidad de aire en el centro histórico de Quito Revista Diseño Urbano \& Paisaje, 35, 50-61 (2019).

9. E.S. Ventzel, L.A. Ovcharov, Theory of Random Processes and its Engineering Application (Moscow, Higher school, 2000).

10. P.P. Oleinik, B.F. Shirshikov, The composition of the sections of organizational and technological documentation and the requirements for their content, Scientific publication (Publishing house of Moscow State University of Civil Engineering, Moscow, 2013),

11. K.Yu. Losev, V.O. Chulkov, R.R. Kazaryan, IOP Conf. Series: Materials Science and Engineering 463032085 (2018).

12. P.P. Oleinik, Organization of planning and management in construction, Scientific publication (ASV Publishing House, 2017)

13. V.N. Kabanov, Organizational and Technological Reliability of the Construction Process (Magazine of Civil Engineering) 1 59-67 (2018). DOI: 10.18720/MCE.77.6.

14. V.N. Kabanov, E.V. Mikhaylova, Definition of Organizational and Technological Reliability of the Construction Organization Economy of construction, 17 67-78 (2012).

15. J. Paslawski, Flexible Approach for Construction Process Management under Risk and Uncertainty, Procedia Engineering, 208 114-124 (2017).

16. M.S. Bassiony, A. Abd El-Karim, O. Nawawy, A.M. Abdel-Alim, Identification and Assessment of Risk Factors Affecting Construction Projects, HBRC Journal, $13202-$ 216 (2017).

17. R. Parsons, The potential influences of environmental perception on human health, J. Environ. Psychol, 11 1-23 (1991).

18. N. Ivanova, O. Ganzha, J. Matec. Conf 106 (2017).

19. A. Wood, P. Bahrami, D. Safarik, Green Walls in High-Rise Buildings (HK, Everbest Printing Co Ltd, 2014)

20. O. Ganzha, Thesis for the degree of candidate of science. Techn. sciences (Moscow, 2009) 